\title{
Kajian Pendekatan Binary Log dalam Change Data Capture
}

\author{
Muhammad Febrian Rachmadhan Amri, I Made Sukarsa I Ketut Adi Purnawan \\ Program Studi Teknologi Informasi Universitas Udayana \\ Bukit Jimbaran, Bali, Indonesia, telp. (0361) 701806 \\ e-mail : rama.febrian@hotmail.com, sukarsa@ee.unud.ac.id, adipurnawan@unud.ac.id
}

\begin{abstract}
Abstrak
Era bisnis yang serba online menyebabkan transaksi terjadi sangat cepat sehingga memungkinkan informasi yang tersimpan dalam data warehouse menjadi tidak valid. Data Warehouse digunakan sebagai media repository data yang mempunyai sifat berorientasi subjek, terintegrasi, time-variant, dan bersifat tetap. Data Warehouse dapat dibangun pengelolaannya menjadi bersifat real time dengan pemanfaatan Change Data Capture. Change Data Capture merupakan teknik yang bisa dijadikan sebagai solusi permasalahan untuk membangun real time data warehousing. Pendekatan binary log dalam change data capture dibuat untuk merekam segala aktivitas manipulasi data yang terjadi pada tingkat On-Line Transactional Processing dan dikelola kembali sebelum disimpan ke dalam Data Warehouse (loading process). Pendekatan binary log dapat meningkatkan kualitas pengelolaan data sehingga tercipta informasi yang valid, karena informasi yang tersedia senantiasa diperbarui. Pengujian menunjukkan bahwa pendekatan Binary Log dalam Change Data Capture mampu menghasilkan pengelolaan data secara real time, informasi terkini yang valid, komunikasi antar sistem yang dinamis, dan pengelolaan data tanpa harus kehilangan satupun informasi dari manipulasi data.
\end{abstract}

Kata kunci: Change Data Capture, Real Time, Data Warehouse, Database Management System, Binary Log

\begin{abstract}
The online business era causes the form of transactions to occur so quickly that the information stored in the data warehouse becomes invalid. Companies are required to have a strong system, which is a system that is real time in order to be able to perform data loading into the media repository that resides on different hosts in the near-real time. Data Warehouse is used as a media repository of data that has the nature of subject-oriented, integrated, timevariant, and is fixed. Data Warehouse can be built into real time management with the advantages possessed and utilize Change Data Capture. Change Data Capture (CDC) is a technique that can be used as problem solution to build real time data warehousing (RTDW). The binary log approach in change data capture is made to record any data manipulation activity that occurs at the OLTP level and is managed back before being stored into the Data Warehouse (loading process). This can improve the quality of data management so that the creation of the right information, because the information available is always updated. Testing shows that Binary Log approach in Change Data Capture (BinlogCDC) is able to generate real time data management, valid current information, dynamic communication between systems, and data management without losing any information from data manipulation.
\end{abstract}

Keyword: Change Data Capture, Real Time, Data Warehouse, Database Management System, Binary Log

\section{Pendahuluan}

Era bisnis yang serba online menyebabkan segala bentuk transaksi bergerak dengan cepat tanpa mengenal waktu. Proses transaksi yang berlangsung terlalu cepat memungkinkan sumber data yang telah mengalami perubahan belum tercatat ke dalam data warehouse saat diperlukan [1]. Data yang tidak up to date menyebabkan informasi yang tersimpan dalam data warehouse sudah tidak valid untuk dijadikan objek analisis [2]. Manipulasi data yang terjadi

Kajian Pendekatan Binary Log dalam Change Data Capture

(Muhammad Febrian Rachmadhan Amri) 
pada sistem dapat direkam dan dimanfaatkan untuk mengatasi permasalahan data yang tidak valid akibat transaksi yang terjadi sangat cepat, sehingga dilakukan suatu kajian mengenai pendekatan binary log dalam membangun change data capture.

Change data capture (CDC) merupakan suatu teknik yang bisa dijadikan sebagai solusi permasalahan untuk membangun real time data warehousing (RTDW). CDC bekerja dengan merekam segala aktivitas yang terjadi pada tabel di level on-line transaction processing (OLTP) sebagai sumber data. CDC dimanfaatkan untuk merekam setiap perubahan yang terjadi pada sumber dalam waktu yang nyata, sehingga data yang mengalami perubahan pada sumber data tiba di data warehouse pada waktu yang mendekati waktu sebenarnya (near-real time) [3]. Mekanisme CDC dikaji untuk diterapkan dalam membangun proses loading data ke dalam data warehouse secara real time. Suatu perusahaan yang tidak menerapkan RTDW memungkinkan tidak menemukan solusi atau inovasi dalam membuat strategi baru yang dapat diterapkan saat pengambilan keputusan [1].

Binary log merupakan suatu plugin yang terdapat pada MySQL yang bisa diaktifkan untuk menjadi log atau catatan dari segala aktivitas yang terjadi pada database. Query digunakan untuk membuka dan membaca informasi yang ada dalam binary log. Informasi yang terkandung dalam binary log merupakan teks yang terenkripsi menjadi bentuk biner. Binary log merupakan catatan riwayat transaksi dan manipulasi yang terjadi pada database [4]. Catatan atau log dapat dimanfaatkan untuk menghindari hilangnya informasi mengenai manipulasi data karena semua catatan aktivitas yang terjadi pada database tercatat secara rinci [5].

\section{Metodologi Penelitian} penelitian.

Metode penelitian membahas tentang perancangan dan metode yang digunakan dalam

\subsection{Gambaran Umum BinlogCDC}

Engine BinlogCDC mencatat dan merekam segala manipulasi data yang terjadi pada OLTP. Keluaran utama dari sistem yang dibuat adalah data yang mengalami perubahan. BinlogCDC harus mampu merekam segala informasi penting yang terkandung dalam binary log. Gambaran umum sistem secara lengkap ditunjukkan pada Gambar 1.

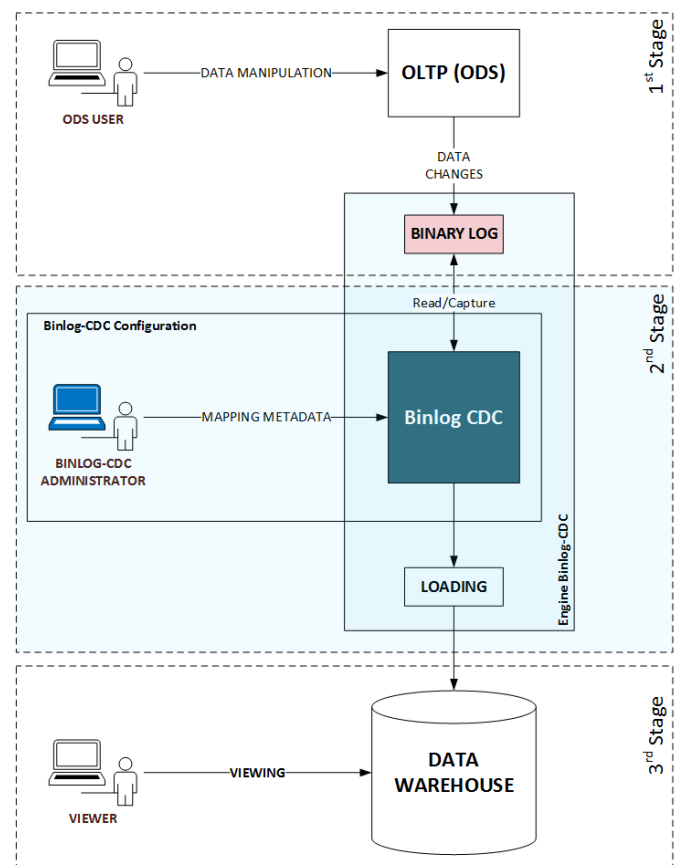

Gambar 1. Gambaran Umum BinlogCDC

Administrator BinlogCDC memegang peranan penting dalam sistem yang dirancang seperti yang digambarkan oleh Gambar 1. Administrator BinlogCDC harus mengerti tentang 
rancangan dimensi fakta dalam Data Warehouse serta memiliki pemahaman untuk memetakan data sumber (ODS) dari OLTP dengan tabel dimensi atau fakta yang menjadi tujuannya (Data Warehouse). Semua pemahaman tentang Data Warehousing diperlukan agar proses loading data dapat dilakukan dengan baik.

\subsection{Kajian Proses BinlogCDC}

BinlogCDC memiliki empat tahapan dalam melakukan capture terhadap perubahan data yang terjadi, berikut merupakan urutan tahapan proses BinlogCDC.

1. Proses Pembacaan Binary Log

2. Proses Pengolahan Isi Binary Log

3. Proses Pengolahan Query

4. Proses Loading Data

Proses pembacaan file binary log digambarkan dengan diagram alir seperti yang terlihat pada Gambar 2.

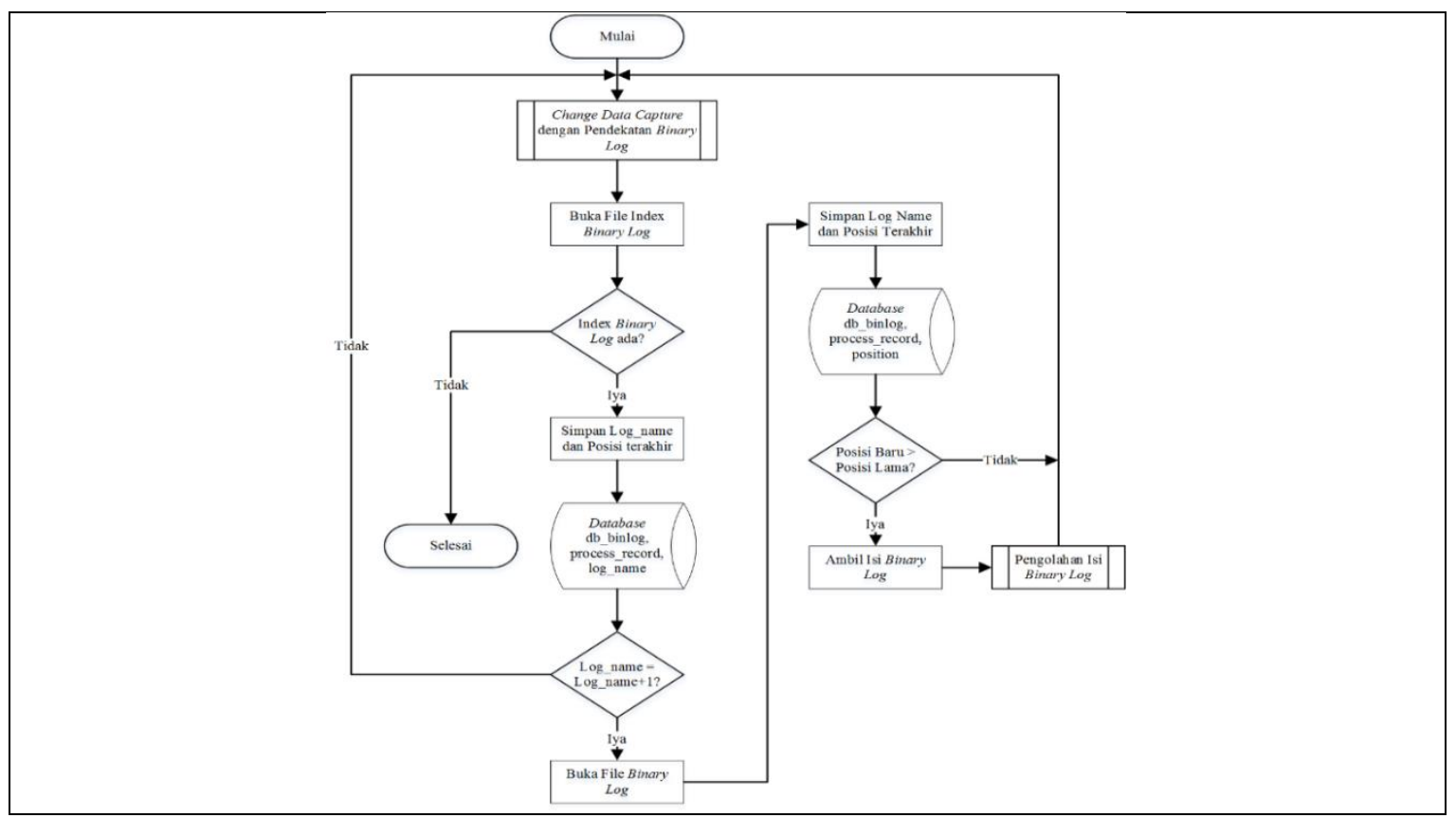

Gambar 2. Alur Proses Pembacaan Binary Log

BinlogCDC berfungsi untuk membaca dan membuka file index dari binary log. Sistem menyimpan satu per satu nama file index beserta posisi terakhir yang ada di dalamnya. Proses pembacaan dilakukan secara berulang hingga sistem menemukan posisi yang bertambah. Posisi yang bertambah menunjukkan adanya manipulasi atau perubahan data. Manipulasi data menjadi pemicu sistem untuk mengambil informasi yang terkandung di dalam binary log dan melakukan proses pengolahan isi dari binary log. 


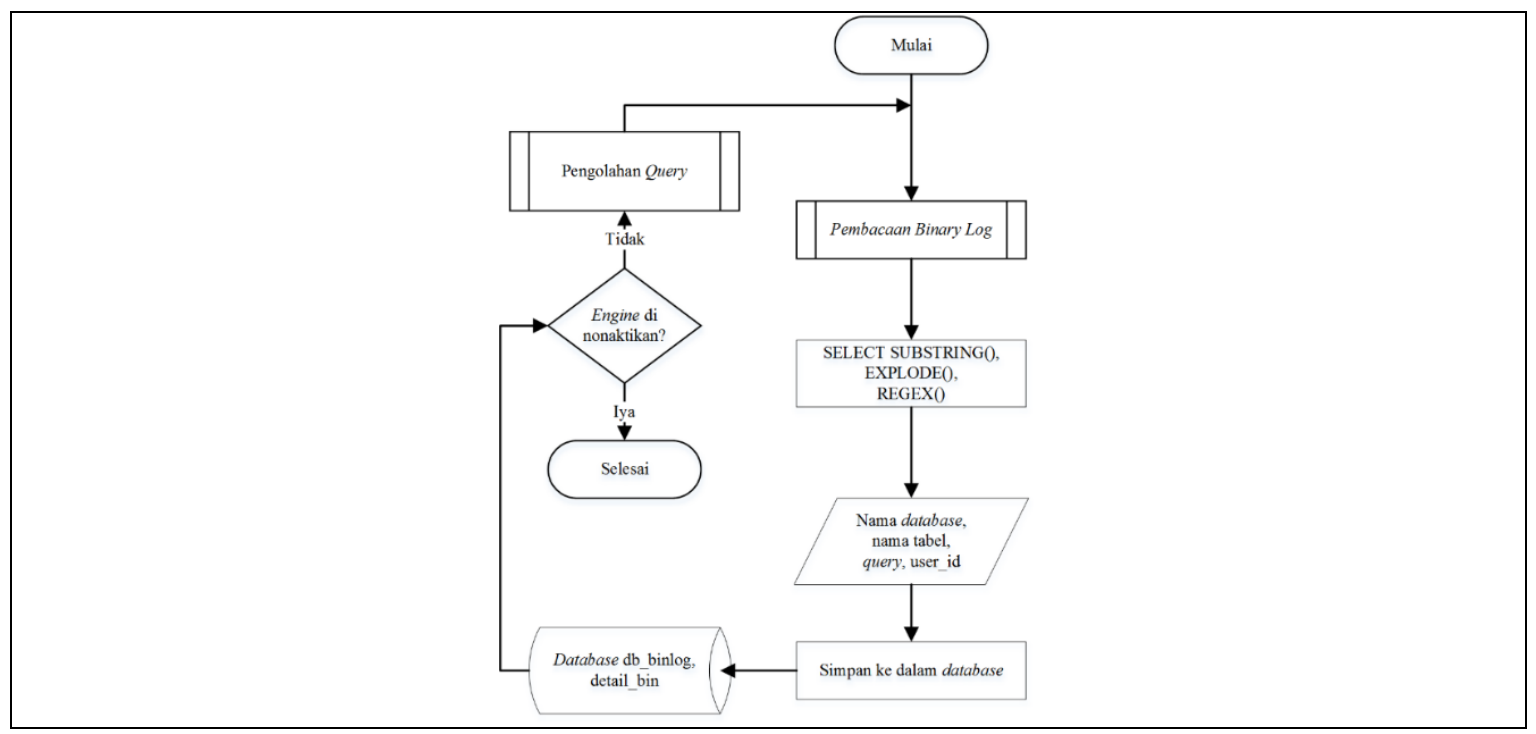

Gambar 3. Alur Proses Pengolahan Isi Binary Log

Pengolahan isi dari binary log memiliki output informasi yang terkandung dalam binary log seperti query, nama file, posisi dimana query dieksekusi, dan beberapa informasi lainnya seperti yang terlihat pada Gambar 3. Fungsi yang digunakan dalam mengolah isi yang ada dalam binary log adalah fungsi string seperti SELECT SUBSTRING(), EXPLODE(), serta REGEX () . Fungsi string digunakan untuk memecah query yang ada di dalam binary log. Tujuan dilakukan pemecahan yaitu untuk mendapatkan nama database dan tabel yang mengalami proses manipulasi. Pemecahan query juga digunakan untuk mendapatkan action atau jenis proses yang dieksekusi, misalnya proses insert, update, atau delete. Informasi yang didapatkan kemudian disimpan ke dalam database sistem.

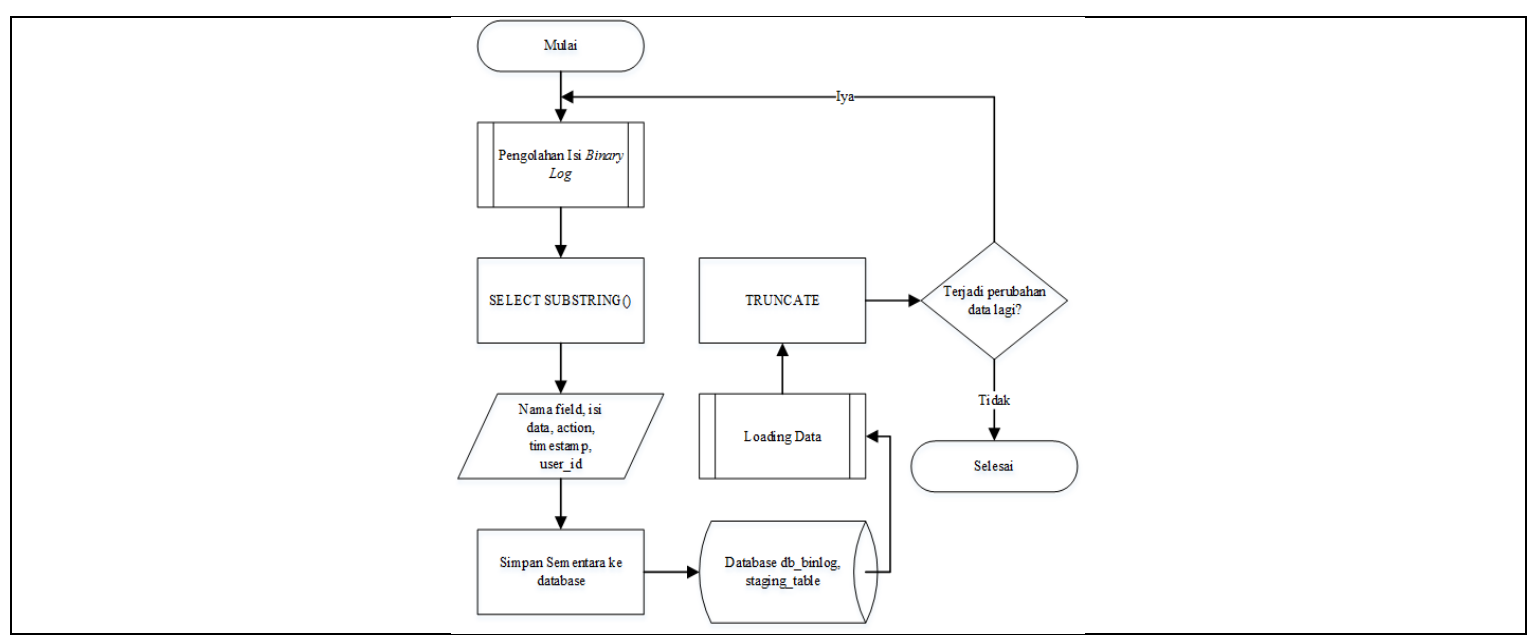

Gambar 4. Alur Proses Pengolahan Query

Proses pada Gambar 4 dinamakan proses pengolahan query. Informasi dari isi binary log yang telah tersimpan, kemudian diolah kembali dengan menggunakan fungsi SELECT SUBSTRING (). Fungsi ini bekerja pada hasil pengolahan query yang sebelumnya dilakukan, sehingga didapatkan informasi mengenai field beserta value. Proses ini menghasilkan informasi yang siap untuk dijadikan acuan dalam melakukan pemetaan metadata sebelum dilanjutkan dengan proses pengiriman data ke dalam data warehouse (loading). 


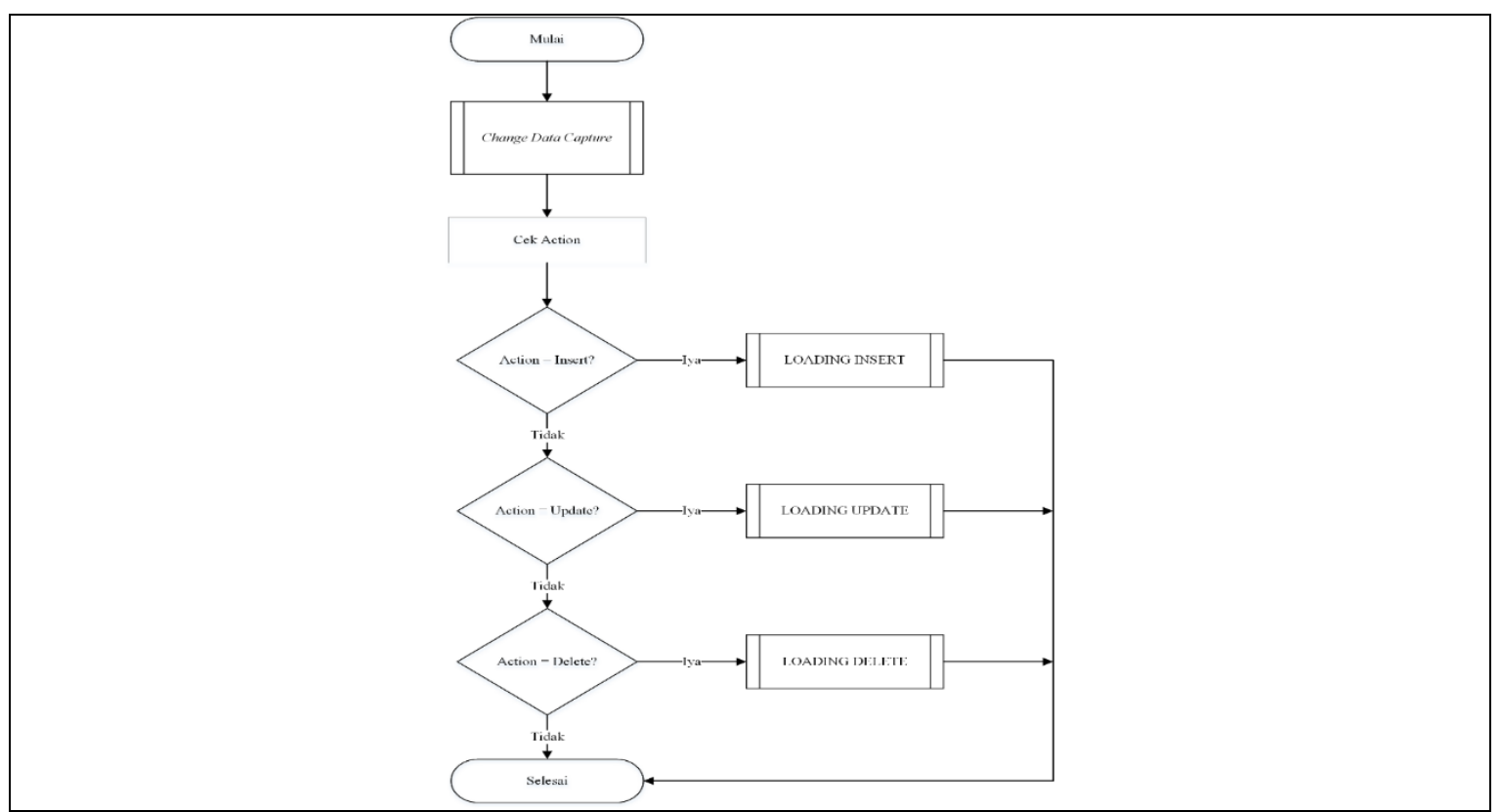

Gambar 5. Alur Proses Loading Data

Informasi dari hasil pengolahan akhir tersimpan secara sementara dalam sebuah tabel staging dan dihapus kembali ketika proses loading telah selesai dilakukan seperti yang terlihat pada Gambar 5. Tabel staging menyimpan informasi mengenai jenis proses apa yang terjadi (action). Terdapat tiga jenis action yaitu insert, update, dan delete, yang masing-masing memiliki mekanisme tersendiri dalam menangani proses loading ke dalam tujuannya.

\subsection{Kajian Proses dalam Binary Log}

File Binary Log memiliki master index yang menampung berbagai macam event dari query yang berjalan.

\begin{tabular}{|c|c|c|}
\hline$\square$ & Log_name & File_size \\
\hline$\square$ & mysql-bin.000459 & 2446 \\
\hline$\square$ & mysql-bin. 000460 & 382 \\
\hline$\square$ & mysql-bin.000461 & 126 \\
\hline$\square$ & mysql-bin.000462 & 17929 \\
\hline$\square$ & mysql-bin. 000463 & 2563 \\
\hline$\square$ & mysql-bin.000464 & 107 \\
\hline
\end{tabular}

Gambar 6. Master Binary Log

Gambar 6 merupakan master binary log yang digunakan sebagai acuan proses perekaman data melalui binary log. Kolom Log_name adalah nama master yang ada. Kolom Pos merupakan posisi terakhir dari isi file master tersebut. BinlogCDC menyimpan nama beserta posisi terakhir dari master setiap saat terjadi perubahan data. Proses ini berfungsi untuk menghindari adanya informasi perubahan data yang terlewatkan untuk direkam.

Posisi binlog memiliki nilai yang dimanfaatkan BinlogCDC untuk menjadi acuan proses pembacaan isi binary log itu sendiri. 


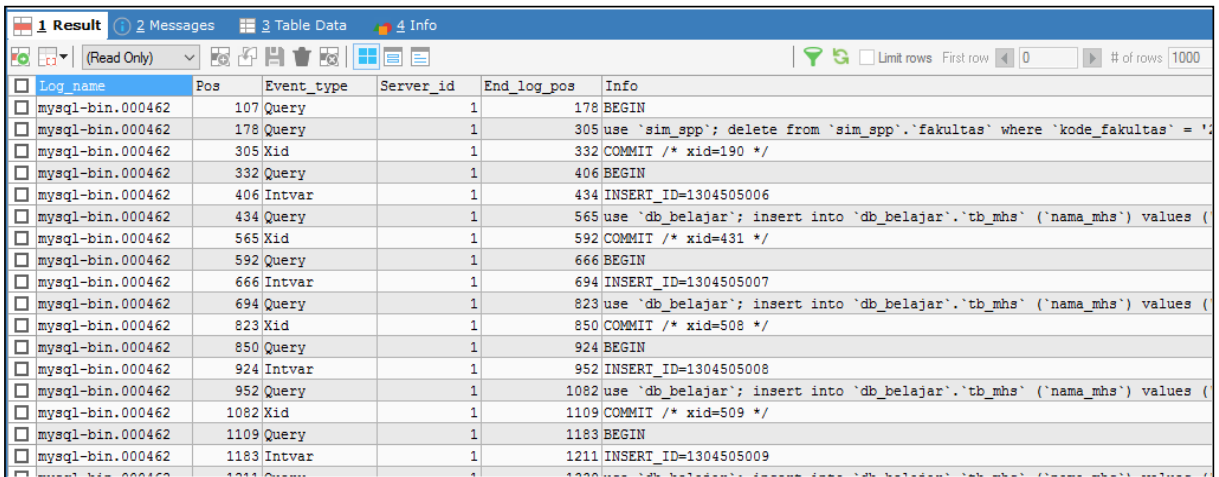

Gambar 7. Binary Log Events

Enam field dalam binary log events yaitu Log_name, Pos, Events, Server_id, End_log_pos, Info. Field Info merupakan informasi yang berisikan query dari aktivitas manipulasi data yang terjadi dalam database. Informasi inilah yang dimanfaatkan dalam membangun sebuah sistem change data capture dengan pendekatan binary log yang ditunjukkan pada Gambar 7.

Penggunaan pendekatan binary log membuat sistem bekerja tanpa harus menyentuh database dari sumber data secara langsung karena query yang ada dalam binary log menjadi satu-satunya acuan proses perekaman. Sumber data tetap aman tanpa harus takut adanya pihak yang mengubah struktur sumber data dengan hak ataupun tanpa hak sekalipun.

\section{Kajian Pustaka}

Pengumpulan teori-teori yang didapatkan dari buku atau internet maupun jurnal yang menunjang pembuatan aplikasi.

\subsection{State of The Art}

Change Data Capture (CDC) merupakan aplikasi yang membaca segala aktivitas yang berhubungan dengan manipulasi data dalam database. Metode yang digunakan dalam membangun CDC yaitu; berdasarkan Database Trigger, Timestamp pada setiap baris data, membaca Log File, dan berdasarkan melakukan partisi secara berjangka [3]. Pendekatan Binary Log cocok digunakan untuk membangun sinkronisasi data secara real time karena segala aktivitas update data yang terjadi pada database dalam MySQL tercatat secara real-time oleh Binary Log. Konfigurasi pada Binary Log juga mudah dilakukan serta memungkinkan untuk diolah pada level aplikasi sebagai acuan untuk mengetahui perubahan data secara real-time. Pemrosesan data yang real time dapat membantu dalam mempercepat pembaruan data pada sebuah instansi ataupun perusahaan yang menggunakan lebih dari satu database dengan host berbeda yang saling terintegrasi [1]. Metode CDC dengan memanfaatkan log scanning dapat menangkap semua berubah data yang berasal dari sumber data dalam durasi yang mendekati waktu sebenarnya tanpa mengubah struktur sistem sumber (ODS) [5].

\subsection{Binary Log}

Binary Log adalah log atau catatan yang berisi semua perintah DML atau insert, update dan delete pada mysql dan menjabarkan secara rinci tentang apa saja query yang digunakan saat melakukan manipulasi data pada database [4]. Struktur binary log terlihat pada Gambar 8.

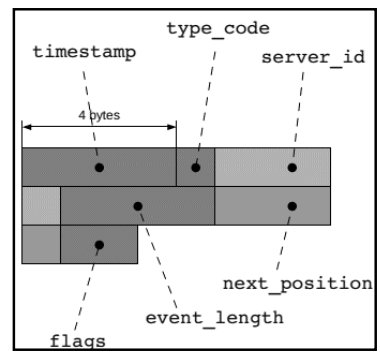




\section{Gambar 8. Struktur Binary Log Events [5]}

Gambar 8 menunjukkan struktur dari Binary Log Event. Binary Log Event adalah informasi dari sebuah Event yang ada pada Binary Log. Adapun bagian dari binary log Event adalah sebagai berikut:

timestamp : catatan waktu eksekusi query

type_code : : kode tipe dari binary log event

server_id : informasi server ID pada sebuah host

event_length : ukuran panjang dari event binlog

next_position : informasi posisi binary log event

Semua perintah atau sintaks disimpan dalam bentuk event yang menjelaskan perubahan atau manipulasi data pada database [4].

Tiga kegunaan mendasar dari Binary Log ini, yaitu :

1. Proses Replikasi, Binary Log digunakan oleh Server Master untuk menyimpan tiap perintah yang dikirim ke Server Slave. Server Master mengirim event log ke dalam Binary Log yang ada di Server Slave, sehingga dengan Binary Log pada Server Slave, Server Slave juga mengalami apa yang dialami oleh Server Master [4].

2. Salah satu proses recovery / restore menggunakan Binary Log. Event pada Binary Log disimpan setelah data backup di-restore. Event tersebut membuat Database restore menjadi up to date di proses backup [4].

3. Proses log scanning atau catatan yang ada pada Binary Log digunakan untuk menjadi acuan dalam membangun CDC [4].

Binary Log juga berisi seberapa jauh tiap perintah melakukan manipulasi pada data, sehingga dapat diketahui aktivitas perubahan yang terjadi pada suatu data atau database [6].

\subsection{Change Data Capture}

Change Data Capture (CDC) adalah teknik untuk merekam aktivitas yang terjadi pada on-line transaction processing (OLTP) sebagai sumber data untuk dilakukannya proses integrasi dengan tujuan datanya. CDC menjadikan integrasi data menjadi lebih efisien dan mengurangi latency antara waktu terjadinya perubahan data dengan data yang tersedia untuk diolah oleh pengguna [7]. Contoh penerapan CDC untuk memecahkan masalah bisnis dijabarkan pada Gambar 9.

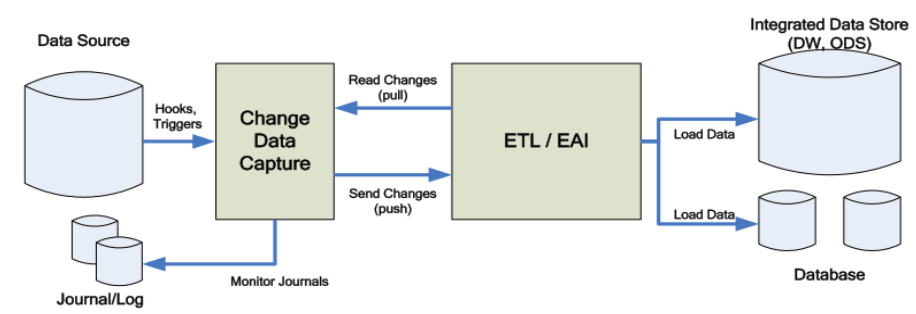

Gambar 9. Infrastruktur Change Data Capture [6]

CDC pada Data Warehouse memerlukan media sebagai perantara agar dapat menangkap segala perubahan yang terjadi pada sumber data. Tiga pendekatan yang memungkinkan untuk digunakan dalam membangun CDC, yaitu; Berdasarkan Trigger, Log Scanning, dan Database Replication [6]. Teknik SCD digunakan untuk mencatat perubahan lambat yang terjadi pada tabel dimensi agar history data yang tersimpan dalam tabel dimensi tidak hilang [8].

\section{Hasil dan Pembahasan}

Hasil dan Pembahasan menjelaskan tentang tahapan-tahapan Change Data Capture dengan Pendekatan Binary Log yang terdiri dari proses metadata mapping, pembacaan binary log dan loading data yang diterapkan pada penelitian ini.

\subsection{Pengujian Sistem}


Langkah awal dalam melakukan pengujian yaitu melakukan pemetaan metadata pada aplikasi BinlogCDC. Pemetaan metadata menjadi acuan engine dalam melakukan proses loading ke dalam tujuan pengiriman data.

\subsubsection{Pemetaan Metadata}

Pemetaan metadata yaitu melakukan konektivitas terhadap tujuan data, dengan memasukkan hostname, username, password, dan port dari koneksi database yang menjadi tujuan. Metadata mapping hanya dapat dilakukan setelah pengguna terkoneksi ke host tujuan. Metadata mapping dimulai dengan memilih sumber data yaitu nama database dari OLTP, dilanjutkan dengan memilih tabel dan field yang ingin diambil datanya untuk keperluan proses loading yang ditunjukan pada Gambar 10.

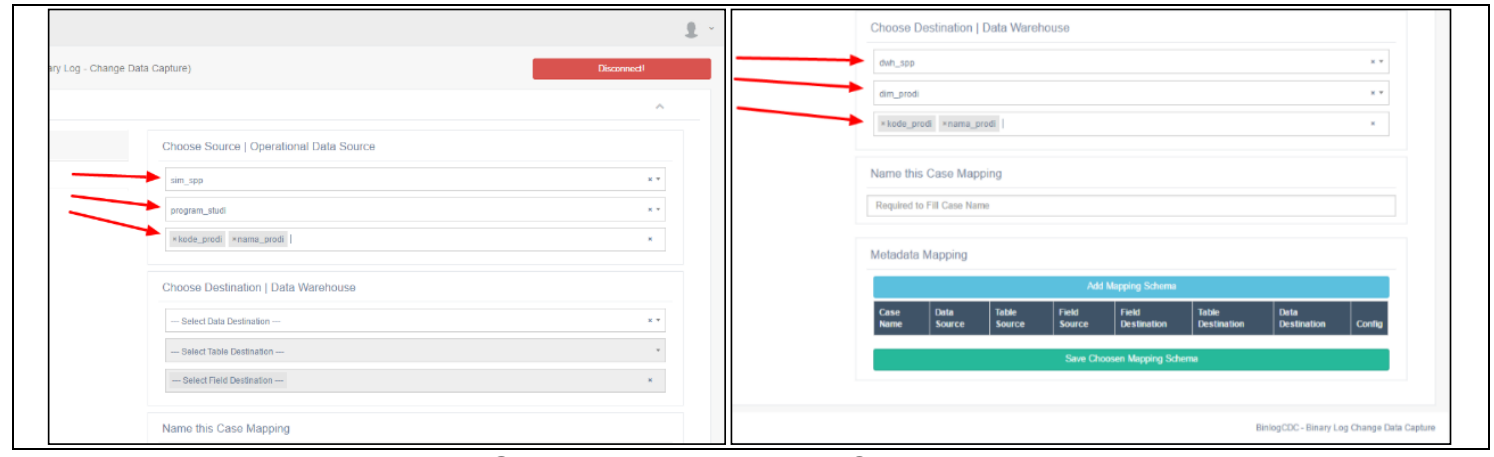

Gambar 10. Pemetaan Sumber Data

Tahap berikutnya yaitu memilih tujuan data. Proses pemilihan tujuan data dimulai dengan memilih nama database, tabel, dan field yang menjadi tujuan pengiriman data.

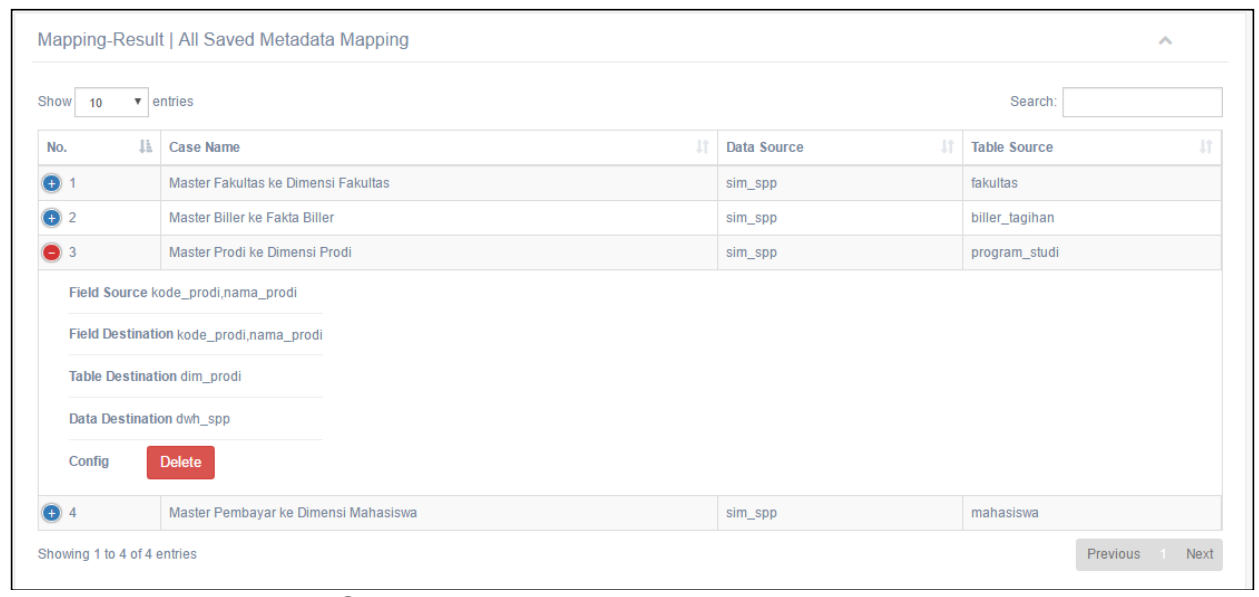

Gambar 11. Hasil Pemetaan Metadata

Hasil dari pemetaan ditampilkan pada halaman Mapping Result seperti yang ditunjukkan Gambar 11. Segala manipulasi data yang dilakukan pada tabel program_studi pada database sim_spp direkam dan dilakukan proses loading ke dalam tabel dim_prodi pada database dwh_spp. Proses pendorongan data dilakukan secara real time, yang mana proses ini merupakan tujuan utama dari dibuatnya change data capture dengan pendekatan binary log.

\subsubsection{Loading Data}

Tahap pengujian berikutnya yaitu melakukan suatu manipulasi pada salah satu data di tabel program_studi yang memiliki tujuan data yaitu tabel dimensi dim_prodi. Manipulasi data yang dilakukan yaitu proses insert, update, dan delete data yang dilakukan pada tabel yang sudah dilakukan pemetaan antara sumber data dengan tujuan data pada tahapan pengujian sebelumnya. 


\begin{tabular}{|c|c|c|}
\hline kode_prodi & nama_prodi & kode_fakultas \\
\hline & 3 Arkeologi & 1 \\
\hline & 4 Teknik Arsitektur & 3 \\
\hline & 5 Teknik Mesin & 3 \\
\hline & 6 Teknik Sipil & 3 \\
\hline & 7 Akuntansi & 2 \\
\hline & 9 Ekonomi Pembangunan & 2 \\
\hline & 10 Manajemen & 2 \\
\hline & 11 Ilmu Hukum & 5 \\
\hline & 13 Matematika & 10 \\
\hline & 14 Sastra Jepang & 1 \\
\hline 2 & 15 Teknologi Informasi & 3 \\
\hline & (0) $(N U L L)$ & (NULL) \\
\hline
\end{tabular}

Gambar 12. Insert data Program Studi

Gambar 12 merupakan tahap melakukan insert data. Data yang dimasukkan adalah nama program studi yaitu "Teknologi Informasi". Primary Key dari tabel ini yaitu kode_prodi dengan id auto increment terakhir adalah "14", sehingga saat data baru ditambahkan pastinya memiliki id yaitu "15".

\begin{tabular}{|c|c|c|c|c|c|}
\hline \multicolumn{6}{|c|}{ dwh_spp.dim_prodi: 14 rows total (approximately) } \\
\hline 2 id & kode_prodi & nama_prodi & start_time & end_time & flag \\
\hline 1 & 1 & Sastra Jawa Kuno & $2017-04-20 \quad 14: 08: 38$ & $0000-00-0000: 00: 00$ & 1 \\
\hline 2 & 2 & Sastra Inggris & 2017-04-20 14:08:50 & 0000-00-00 00:00:00 & 1 \\
\hline 3 & 3 & Arkeologi & 2017-04-20 14:09:02 & $0000-00-0000: 00: 00$ & 1 \\
\hline 4 & 4 & Teknik Arsitektur & 2017-04-20 14:09:14 & 0000-00-00 00:00:00 & 1 \\
\hline 5 & 5 & Teknik Mesin & 2017-04-20 14:09:50 & 0000-00-00 00:00:00 & 1 \\
\hline 6 & 6 & Teknik Sipil & 2017-04-20 14:10:02 & 0000-00-00 00:00:00 & 1 \\
\hline 7 & 7 & Akuntansi & 2017-04-20 14:10:15 & 0000-00-00 00:00:00 & 1 \\
\hline 13 & 9 & Ekonomi Pembangunan & 2017-04-20 14:15:38 & $0000-00-0000: 00: 00$ & 1 \\
\hline 14 & 10 & Manajemen & $2017-04-2014: 16: 15$ & $0000-00-0000: 00: 00$ & \\
\hline 15 & 11 & Ilmu $\mathrm{HL}$. & 2017-04-21 16:02:54 & $0000-0 \quad-00: 00: 00$ & 1 \\
\hline 16 & 12 & Farmas & 2017-04-21 16:48:38 & $2017-0)-16: 48: 52$ & \\
\hline 17 & 13 & Maten tik 7 & $2017-04-2116: 48: 52$ & $0000-60-700: 00: 00$ & \\
\hline 18 & 14 & Sastra ang & $2017-04-27$ 19:10:18 & $0000-0) / 000: 00: 00$ & \\
\hline 19 & 15 & Teknolog Informasi & $2017-04-27$ 19:13:22 & $0000-00-0000: 00: 00$ & \\
\hline
\end{tabular}

Gambar 13. Hasil Capture Insert Data pada Tujuan Program Studi

Gambar 13 merupakan data hasil capture yang telah sampai ke dalam tujuan data. Data dengan kode prodi "15" dan nama_prodi "Teknologi Informasi" telah masuk dengan start time "2017-04-27 19:13:22" yang merupakan waktu dilakukan penambahan data pada sumber data. Kolom end time bernilai kosong karena data masih ada dan aktif pada sumber data. Kolom flag bernilai "1" untuk data yang masih aktif.

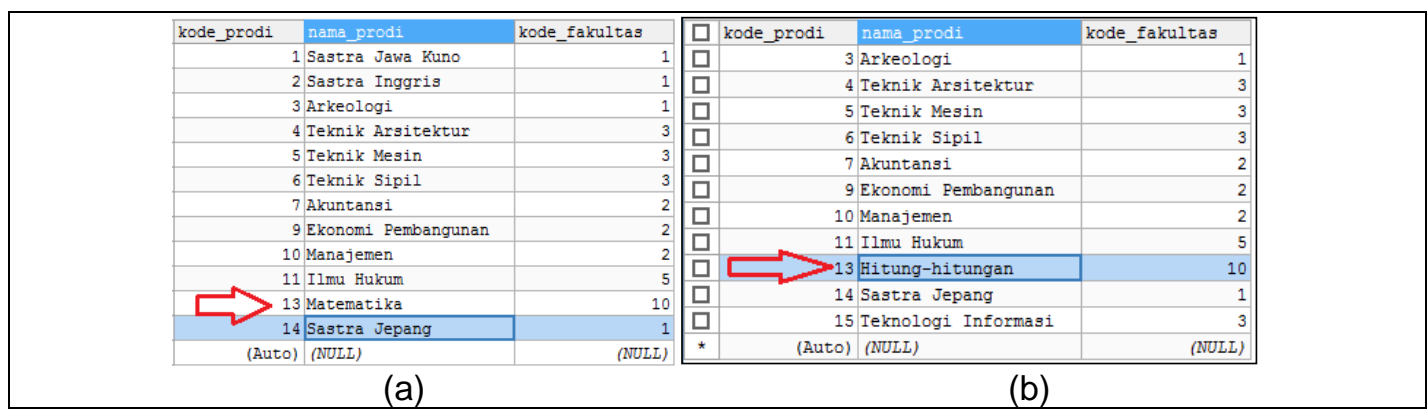

Gambar 14. (a) Data Awal (b) Hasil Update data Program Studi

Gambar 14 merupakan pengujian tahap kedua yaitu update data yang dilakukan pada data dengan kode_prodi "13" (a). Data yang diubah memiliki nama_prodi awal yaitu "Matematika" dan diubah menjadi "Hitung-hitungan" (b). 


\begin{tabular}{|c|c|c|c|c|c|}
\hline \multicolumn{6}{|c|}{ dwh_spp.dim_prodi: 15 rows total (approximately) } \\
\hline 2 id & kode_prodi & nama_prodi & start_time & end_time & flag \\
\hline 1 & 1 & Sastra Jawa Kuno & $2017-04-20$ 14:08:38 & 0000-00-00 00:00:00 & 1 \\
\hline 2 & 2 & Sastra Inggris & 2017-04-20 14:08:50 & 0000-00-00 00:00:00 & 1 \\
\hline 3 & 3 & Arkeologi & $2017-04-20$ 14:09:02 & 0000-00-00 00:00:00 & 1 \\
\hline 4 & 4 & Teknik Arsitektur & 2017-04-20 14:09:14 & 0000-00-00 00:00:00 & 1 \\
\hline 5 & 5 & Teknik Mesin & $2017-04-20$ 14:09:50 & $0000-00-0000: 00: 00$ & 1 \\
\hline 6 & 6 & Teknik Sipil & $2017-04-2014: 10: 02$ & $0000-00-0000: 00: 00$ & 1 \\
\hline 7 & 7 & Akuntansi & $2017-04-2014: 10: 15$ & $0000-00-0000: 00: 00$ & 1 \\
\hline 13 & 9 & Ekonomi Pembangunan & 2017-04-20 14:15:38 & 0000-00-0qण :00:00 & 가 \\
\hline 14 & 10 & Manajemen & 2017-04-20 14:16:15 & 0000-00-0d of:00:00 & \\
\hline 15 & 11 & Ilmu Hukum & 2017-04-21 16:02:54 & 0000-00-0, of:00:00 & \\
\hline 16 & 12 & Farmasi & $2017-04-2116: 48: 38$ & $2017-04-21 \sqrt{6: 48: 52}$ & \\
\hline 17 & $>13$ & Matematika & $2017-04-2116: 48: 52$ & $2017-04-2719: 15: 20$ & 0 \\
\hline 18 & 14 & Sastra Jepang & $2017-04-2719: 10: 18$ & $0000-00-0000: 00: 00$ & 1 \\
\hline 19 & 15 & Teknologi Informasi & $2017-04-27$ 19:13:22 & $0000-00-0000: 00: 00$ & 1 \\
\hline 20 & $>13$ & Hitung-hitungan & $2017-04-2719: 15: 20$ & $0000-00-0000: 00: 00$ & 1 \\
\hline
\end{tabular}

Gambar 15. Hasil Capture Update Data pada Tujuan Program Studi

Data yang dimanipulasi telah direkam dan hasil capture data terlihat pada Gambar 15. Data lama pada tujuan tidak diubah ataupun dihapus, hanya terjadi pengisian waktu terjadinya manipulasi pada kolom end_time dan mengganti nilai pada kolom $\mathrm{fl}$ lag dari " 1 " menjadi "0". Data baru hasil capture memiliki id sumber data yang sama. Aturan dasar dari konsep data warehouse adalah selalu menyimpan riwayat perubahan dan manipulasi yang dilakukan pada sumber data. Data "Hitung-hitungan" pada kolom nama_prodi telah sampai pada tujuan data dengan flag bernilai "1" yang menandakan bahwa data dengan nama_prodi "Matematika" telah diubah menjadi "Hitung-hitungan".

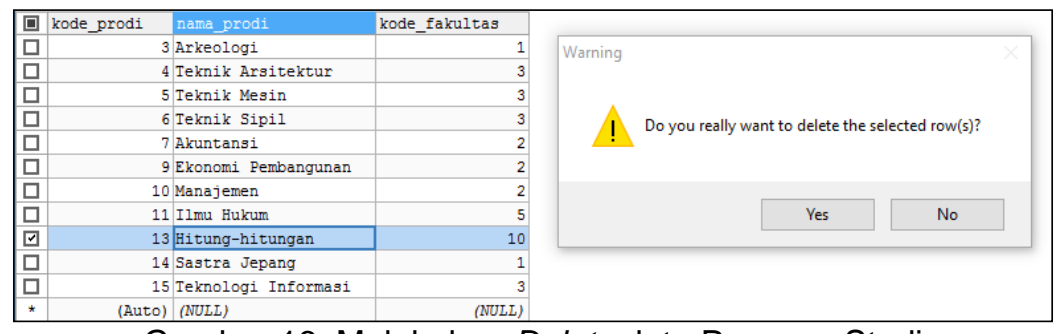

Gambar 16. Melakukan Delete data Program Studi

Tahap terakhir merupakan proses menghapus data pada tabel program_studi. Proses delete data yang dilakukan yaitu pada data dengan kode_prodi "13". Proses penghapusan data terlihat pada Gambar 16.

\begin{tabular}{|c|c|c|c|c|c|}
\hline \multicolumn{6}{|c|}{ dwh_spp.dim_prodi: 15 rows total (approximately) } \\
\hline$\rho$ id & kode_prodi & nama_prodi & start_time & end_time & flag \\
\hline 1 & 1 & Sastra Jawa Kuno & $2017-04-20 \quad 14: 08: 38$ & $0000-00-0000: 00: 00$ & 1 \\
\hline 2 & 2 & Sastra Inggris & 2017-04-20 14:08:50 & 0000-00-00 00:00:00 & 1 \\
\hline 3 & 3 & Arkeologi & 2017-04-20 14:09:02 & 0000-00-00 00:00:00 & 1 \\
\hline 4 & 4 & Teknik Arsitektur & 2017-04-20 14:09:14 & $0000-00-0000: 00: 00$ & 1 \\
\hline 5 & 5 & Teknik Mesin & 2017-04-20 14:09:50 & 0000-00-00 00:00:00 & 1 \\
\hline 6 & 6 & Teknik Sipil & 2017-04-20 14:10:02 & 0000-00-00 00:00:00 & 1 \\
\hline 7 & & Akuntansi & 2017-04-20 14:10:15 & 0000-00-00 00:00:00 & 1 \\
\hline 13 & 9 & Ekonomi Pembangunan & 2017-04-20 14:15:38 & 0000-00-00 00:00:00 & 1 \\
\hline 14 & 10 & Manajemen & 2017-04-20 14:16:15 & 0000-00-00 00:00:00 & 1 \\
\hline 15 & 11 & Ilmu Hukum & 2017-04-21 16:02:54 & 0000-00-00 00:00:00 & 1 \\
\hline 16 & 12 & Farmasi & 2017-04-21 16:48:38 & 2017-04-21 16:48:52 & \\
\hline 17 & 13 & Matematika & 2017-04-21 16:48:52 & $2017-04-27] 1015: 20$ & \\
\hline 18 & 14 & Sastra Jepang & 2017-04-27 19:10:18 & $0000-00-0400500: 00$ & \\
\hline 19 & 15 & Teknologi Informasi & $2017-04-27$ 19:13:22 & $0000-00-00 \bigvee: 00: 00$ & V \\
\hline 20 & 13 & Hitung-hitungan & $2017-04-27$ 19:15:20 & $2017-04-27$ 19:17:04 & 0 \\
\hline
\end{tabular}

Gambar 17. Hasil Capture Delete Data pada Tujuan Program Studi

Gambar 17 menunjukan bahwa hasil capture dari proses menghapus data yang dilakukan pada sumber data telah sampai hasilnya ke dalam tujuan data. Data warehousing memiliki konsep bahwa data yang dihapus pada sumber data, tidak hilang pada tujuan datanya. Data pada tujuan hanya diberikan nilai waktu pada kolom end time dan pada kolom flag nilainya diubah menjadi "0" yang membuktikan data telah berakhir masa aktifnya karena sudah tidak ada pada sumber data. 


\subsection{Analisa Hasil Pengujian}

Berdasarkan hasil uji coba dapat diketahui bahwa sistem yang dibuat mampu mengatasi permasalahan-permasalahan yang dikemukakan sebelumnya, yaitu :

1. Implementasi sistem memiliki sifat dinamis yang tinggi untuk diimplementasikan pada mesin basis data MySQL dan sangat efektif untuk dipasang pada sistem data warehouse yang memerlukan kebaruan data terkini.

2. Sistem dapat melakukan proses capture pada data dalam sumber data yang mengalami manipulasi insert, update, dan delete yang kemudian langsung diolah untuk didorong ke dalam tujuan data.

3. Sistem sama sekali tidak menyentuh database dari sumber data dalam bentuk proses apapun seperti select atau view dan tidak harus mengubah struktur tabel data sumber seperti halnya menambahkan kolom flag sebagai penanda, karena sistem menggunakan pendekatan binary log dan murni hanya binary log sebagai acuan dalam membangun suatu engine change data capture berbasis binary log.

4. Sistem berhasil merekam segala aktivitas manipulasi data tanpa terlewatkan sedikitpun meskipun terjadi banyak transaksi dan file master binary log telah mengalami pergantian ketika engine dalam keadaan dimatikan. Keberhasilan ini dikarenakan setiap kali proses pembacaan informasi dalam binary log dilakukan, sistem selalu menyimpan nama file master beserta posisi terakhirnya, sehingga tidak memungkinkan adanya informasi yang terlewatkan ataupun terduplikasi.

\subsection{Perbandingan BinlogCDC dengan sistem CDC yang telah ada sebelumnya}

Perbandingan sistem BinlogCDC dengan beberapa sistem CDC yang telah ada sebelumnya ditampilkan dalam bentuk tabel yaitu pada Tabel 1 .

Tabel 1. Perbandingan Jenis-Jenis CDC

\begin{tabular}{|c|c|c|c|c|}
\hline Cdc Approach & $\begin{array}{c}\text { Process Capture } \\
\text { Speed }\end{array}$ & $\begin{array}{l}\text { Dynamic Data } \\
\text { Source }\end{array}$ & $\begin{array}{l}\text { Host To } \\
\text { Host }\end{array}$ & Accuration \\
\hline Base on Trigger & Fast & No & No & Good \\
\hline Replication Method & Mid & No & Yes & Good \\
\hline $\begin{array}{l}\text { Comparing Source and Target by } \\
\text { Using Crc }\end{array}$ & Slow & Yes & Yes & Mid \\
\hline $\begin{array}{l}\text { Full Comparing Source and } \\
\text { Target }\end{array}$ & Slow & Yes & Yes & Bad \\
\hline Binary Log Approach & Fast & Yes & Yes & Good \\
\hline
\end{tabular}

Perbandingan pada Tabel 1 berlaku jika sistem sudah berjalan dengan sempurna dan telah diaplikasikan dengan melakukan konfigurasi binary log pada DBMS yang digunakan. CDC dengan memanfaatkan Trigger merupakan pendekatan CDC yang memiliki proses capture tercepat, yaitu satu detik hingga lima belas detik untuk sekali proses. Pendekatan binary log dapat melakukan proses capture tiga detik hingga sepuluh detik untuk sekali proses. Tiga detik pertama merupakan waktu yang terpakai untuk melakukan koneksi jika server tujuan data memiliki host yang berbeda. Pendekatan binary log memiliki kinerja yang lebih baik dibandingkan metode ataupun pendekatan yang telah ada sebelumnya dalam berbagai aspek.

\subsection{Kelebihan dan Kekurangan}

Pembuatan suatu sistem tentunya memiliki kelebihan maupun kekurangan sesuai dengan metode dan proses-proses yang digunakan. Tujuan dari dibangunnya sebuah model pengembangan adalah untuk menangani kekurangan-kekurangan pada sistem yang ada sebelumnya. Aplikasi BinlogCDC ini memiliki kelebihan-kelebihan diantaranya :

1. Kecepatan proses capture data hingga proses loading data ke tujuan menggunakan BinlogCDC dapat dikatakan maksimal dan mendekati waktu yang sebenarnya.

2. Sumber data yang dinamis dapat memudahkan pengimplementasian sistem terhadap berbagai database tanpa harus mengubah ataupun menambah kolom bantuan pada tabel bantu yang menjadi sumber data.

3. Tujuan data dapat berada pada host yang berbeda,

4. Pemrosesan data yang real time dapat membantu dalam mempercepat perbaruan data dalam sebuah instansi ataupun perusahaan. 
5. Penanganan masalah ketika engine mati akibat server yang down berhasil dilakukan, sehingga tidak lagi terjadi hilangnya informasi akibat manipulasi data.

6. Penggunaaan pendekatan binary log membuat sistem bekerja tanpa harus menyentuh database dari sumber data secara langsung karena query yang ada dalam binary log adalah satu-satunya acuan. Sumber data tetap aman tanpa harus takut adanya pihakpihak yang mengubah struktur sumber data tanpa hak.

Aplikasi yang dikembangkan pastilah memiliki kekurangan, begitu pula halnya dengan sistem BinlogCDC. Kekurangan yang ada pada aplikasi BinlogCDC antara lain:

1. Konfigurasi binary log saat awal pemasangan sistem harus dilakukan dengan benar terlebih dahulu. Konfigurasi juga harus dilakukan pada level DBMS karena belum ditemukan cara menjalankan query binary log melalui level aplikasi.

2. BinlogCDC hanya terfokus pada proses capture terhadap data yang mengalami perubahan atau dimanipulasi sehingga belum adanya proses ETL lainnya seperti data cleansing.

3. Aplikasi harus dipasang pada host yang sama dengan sumber data karena belum ditemukan cara pengolahan binary log dari server memiliki host berbeda.

\section{Kesimpulan}

Hasil pengujian dari pemanfaatan binary log dalam change data capture menunjukkan aplikasi sudah berfungsi dan memberikan hasil yang sesuai dengan konsep dasar change data capture dengan delay waktu yang mendekati waktu sebenarnya. Proses real time memanfaatkan time delay sehingga engine dapat dikonfigurasikan sesuai dengan pengaturan durasi time delay. Engine BinlogCDC memakan waktu minimal tiga detik dan maksimal sepuluh detik untuk sekali melakukan proses capture hingga loading data. BinlogCDC menjadikan informasi yang tersedia dalam data warehouse sebagai tujuan data, selalu diperbarui setiap saat terjadinya manipulasi atau perubahan pada OLTP sebagai sumber data sehingga informasi terkini yang tersimpan menjadi valid. Komunikasi antar sistem dapat dilakukan secara dinamis yaitu sumber dengan tujuan data yang berbeda host dapat dilakukan dengan struktur sumber data yang dinamis, sehingga tidak harus merombak sistem pada level coding. Pemanfaatan binary log untuk CDC dapat mengatasi masalah terkait pengelolaan data yang diakibatkan oleh matinya engine ataupun transaksi yang bergerak terlalu cepat dan menyebabkan banyak informasi yang terlewatkan.

\section{Daftar Pustaka}

[1] I. G. S. Aryandana, I. M. Sukarsa, and P. W. Buana, "Pembentukan Data Mart Menggunakan Metode Generalization", Lontar Komputer., vol. 7, no. 3, pp. 814-825, 2016.

[2] W. M. M. Ali. Abdelmgeid A, "Monitoring Business Transactions for a Real-time Data Warehouses", International Journal of Computer Applications, vol. 146, no. 8, pp. 8-11, 2016.

[3] Sukarsa. I Made, et al, "Change Data Capture on OLTP Staging Area for Nearly Real Time Data Warehouse base on Database Trigger", International Journal of Computer Applications, vol. 52, no. 11, pp. 32-37, 2012.

[4] G. H. Surya, I. M. Sukarsa, I. G. Made, and A. Sasmita, "Two-Ways Database Synchronization in Homogenous Database Management System", vol. 65, no. 1, 2014.

[5] J. G. Shi, Y. Bin Bao, F. L. Leng, and G. Yu, "Study on log-based change data capture and handling mechanism in real-time data warehouse", Proc. - Int. Conf. Comput. Sci. Softw. Eng. CSSE 2008, vol. 4, pp. 478-481, 2008.

[6] M. Kindahl and L. Thalmann, An API for Reading the MySQL Binary Log. Oracle.

[7] Atunnity, "Efficient and Real Time Data Integration with Change Data Capture", 2009, no. Cdc, pp. 1-20.

[8] W. Wisswani, "Penerapan Hybrid Slowly Change Dimension untuk Nearly Realtime Datawarehouse", Lontar Komputer, vol. 4, no. 1, pp. 215-223, 2013. 